\title{
Danzig: The Missing Link in the History of Flags of Convenience
}

\section{Rodney Carlisle}

Le système d'immatriculation des navires de Danzig est connu pour être un précurseur du pavillon de complaisance du Panama. Le pavillon de Danzig est également connu pour avoir abrité les navires de la flotte Bapico, filiale d'Esso, de 1920 jusqu'en 1935. Le présent article complète ces informations et fournit de nouvelles informations sur le pavillon de Danzig comme une forme précoce du pavillon de complaisance du 20ème siècle, en particulier pour les pétroliers. $L$ 'article résume également certaines données concernant un nombre de compagnies marchandes régionales, propriétaires de navires, pendant cette période. L'article montre comment la relation spéciale de Danzig avec l'Allemagne et son statut de mini-état annonçaient le développement des pavillons de complaisance et des immatriculations secondaires dans la deuxième moitié du 20 e siècle.

During the reparations discussions at the end of World War I, Standard Oil (Esso) fought to keep ships of its subsidiary, Deutsch-Amerikanischer Petroleum Gesellschaft (DAPGmbH), Hamburg from being seized and transferred to Britain or France. Four ships were successfully retained by Standard Oil in a new firm, Baltic-American Petroleum Import Company (Bapico), established in The Free City of Danzig. ${ }^{1}$ A thorough (and semi-official) history of the Standard Oil Company, states of Bapico: "This company had been organized in 1919 to take over the tankers being built for Jersey's German affiliate. Because of its domicile in what became the Free City of Danzig in January 1920, under the Treaty of Versailles, its tankers were immune from seizure under the reparations provisions of that treaty."2

The Riedemann shipping company that operated the ships established Bapico,

1 Internet resources, computer access to newspaper archives, email communication with international scholars, and some secondary works published in recent years have facilitated the amplification of material and correction of minor details as published in Rodney Carlisle, Sovereignty For Sale: The Origin and Evolution of the Panamanian and Liberian Flags of Convenience (Annapolis: Naval Institute Press, 1981).

2 Henrietta M. Larson, Evelyn H. Knowlton, and Charles S. Popple, History of Standard Oil Company (New Jersey): New Horizons, $1927-1950$ (New York: Harper and Row, 1974), 305.

The Northern Mariner/le marin du nord, XXIII No. 2, (April 2013), 135-150 
resident in Danzig, and transferred to the new company four petroleum tankers of the Deusche-Americanische Petroleum Gesellschaft (DAPG) fleet, the Zoppot, Gedania, Vistula, and Baltic. The Reparations Commission decided that the ships, as Danzig ships, were not deliverable as part of the reparations to the victorious Allies. ${ }^{3}$

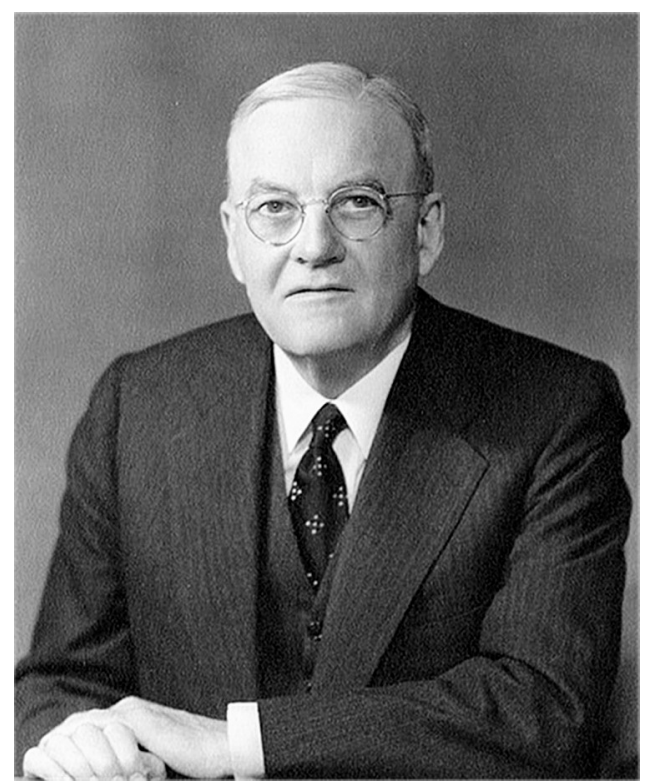

Illustration 1: With his brother Allen, John Foster Dulles of Sullivan and Cromwell was instrumental in protecting the Germanbased Esso fleet of tankers from seizure as part of Allied reparations after World War I.

The law firm providing advice to Standard Oil at that time was Sullivan and Cromwell; one of the young attorneys with the firm was John Foster Dulles. During the Paris discussions over reparations, John Foster Dulles served there under his uncle, Secretary of State Robert Lansing. Allen Dulles, John Foster's brother, was in and out of the State Department in the period, and he was also an attorney for Sullivan and Cromwell; later, he served with the OSS and was the first Director of the CIA. It is well to keep in mind that Sullivan and Cromwell had masterminded the recovery of Standard Oil from the Anti-Trust decision of 1911, and had an established reputation for finding the most convenient jurisdiction (in the U.S) for state incorporations, an expertise that appears to have provided a model in later years for finding the most convenient jurisdiction internationally for ship registry. ${ }^{4}$ While the discussions regarding reparations were going on, John Foster Dulles reported that he met with a Mr. F.D. Asche, from Esso, in Paris to discuss the reluctance of Esso to see its ships be part of reparations as required under the Treaty of Versailles. ${ }^{5}$ Under the reparations decisions, Germany had to surrender to the Allies all of its sea-going merchant fleet, some 625 ships, together with 91 interned in the United States, and 121 "embargo" vessels originally of German registry, but already confiscated and interned in

3 QQ Reparations Commission, RG 45, U.S. National Archives, 14 August 1920. The first four ships, Vistula, Baltic, Gedania, and Zoppot have been confirmed from Lloyd's; the Niobe, previously owned by DAPG, was transferred first to the United States, and then, in 1927, to Danzig.

4 William Nelson Cromwell was special representative of Panama: Gustavo A. Mellander, The United States in Panamanian Politics: The Intriguing Formative Years (Danville, IL: Interstate Publishers, 1971), as well Peter Grose, Gentleman Spy (New York: Houghton Mifflin, 1991). There is quite a "New Left" literature denouncing the role of Sullivan and Cromwell in "regime change" in several countries, summarized and cited in Stephen Kinzer, Overthrow (New York: Times Books, 2007).

5 John Foster Dulles Papers, Diaries and Journals, Seeley Mudd Library, Princeton, Box 278, 29 July1919. 
Allied countries. Total tonnage of these ships was over 4 million GRT. ${ }^{6}$ For Esso, the German-owned fleet of its subsidiary was at also risk, until the decision to re-flag in Danzig.

Although largely German in population, Danzig (now Gdansk) was given a special status as a Free City because of the need to provide Poland with an outlet to the sea. Poland was to administer Danzig's foreign affairs, and have certain special rights in the city and harbor of Danzig, but the city was to be self-governing under League of Nations protection. Its anomalous status later became one of Hitler's excuses for invasion of Poland in 1939, and some of the first shots of World War II in Europe were fired when a

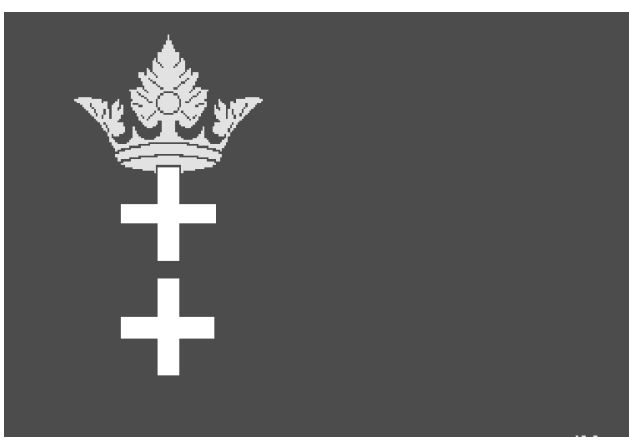

Illustration 2: With its distinctive double white crosses and gold crown on a field of red, the Danzig flag was familiar in seaports around the world in the 1920s, sheltering a total of 35 Esso tankers, first from confiscation, and then from Germany's social and economic upheaval.

German ship opened fire on Polish facilities in the city.

However, from 1920 to 1939, Danzig remained a self-governing state with almost all the characteristics of an independent nation. Among these was the ability to offer its merchant flag to ships registered in Danzig, affirmed in its constitution and recognized in its treaty with Poland. Danzig's merchant flag was a stylized representation

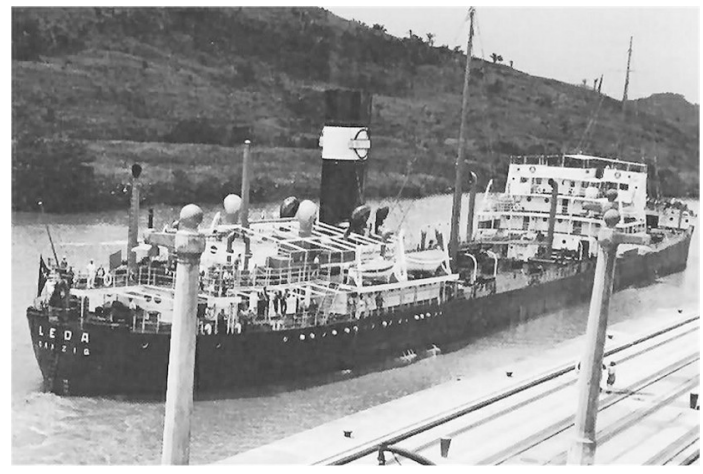

Illustration 3: The Danzig-registered Esso tanker Leda of the Bapico Fleet transiting the Panama Canal. The flag and home port can be seen in this photo, as well as the " $R$ " stack emblem, denoting the "Reidemann Line." of an ancient city flag, with a yellow crown surmounting two crosses on a field of red. The same stylized representation, with a crown and two crosses, appeared on postage stamps and on the reverse of the gulden coins introduced in 1924. It was a wellrecognized symbol throughout Northern Europe.

Between 1920 and 1934, the Bapico fleet grew to a total of some 32 ships. Seven of them were transferred out before 1935 to other countries (Belgium, Britain, France, Germany, Italy, and the United States). It appears that the profits from the trips of the Bapico line

6 http://www.wintersonnenwende.com/scriptorium/english/archives/articles/germanypaid.html: "What Germany has paid under the Treaty of Versailles," by Lujo Brentano, Professor at the University of Munich. Walter de Gruyter \& Co., Berlin und Leipzig 1923. Vormals G. J. Göschen'sche Verlangshandlung - J. Guttentag, Verlagsbuchhandlung - Georg Reimer - Karl J. Trübner - Veit \& Comp. This digitalized version (C) 2009 by The Scriptorium. 
wereplowed back into the purchase of new ships, most built in Germany. In 1935, the remaining 25 ships were transferred to Panama. Table I shows Bapico tanker ship names, their years of registry in Danzig, and the date and destination when they were transferred out to another registration. As shown on the table, all but three of the fleet were new, diesel motor-powered tankers, rather than steam-powered.

\section{Table 1: Bapico Tankers in Danzig.}

\begin{tabular}{|c|c|c|c|}
\hline Ship Name & Motor or Steam & Years in Danzig & Transfer to \\
\hline Baltic & steam & $1920-35$ & Panama \\
\hline Calliope & motor & $1926-35$ & Panama \\
\hline Clio & motor & $1926-35$ & Panama \\
\hline D.L. Harper & motor & $1933-35$ & Panama \\
\hline F.H. Bedford & motor & $1930-35$ & Panama \\
\hline F.J. Wolfe & motor & $1932-35$ & Panama \\
\hline Franz Klazen & motor & $1932-35$ & Panama \\
\hline Gedania & steam & $1919-33$ & Germany \\
\hline George W. McKnight & motor & $1933-35$ & Panama \\
\hline Hanseat & motor & $1929-35$ & Panama \\
\hline Harry G. Seidel & motor & $1930-35$ & Panama \\
\hline Heinrich V. Reideman & motor & $1930-35$ & Panama \\
\hline J.A. Mowinckle & motor & $1930-35$ & Panama \\
\hline J.H. Senior & motor & 1931-35 & Panama \\
\hline Josiah Macy & motor & $1924-35$ & Panama \\
\hline Leda II & motor & $1925-35$ & Panama \\
\hline Niobe & motor & $1927-35$ & Panama \\
\hline Orville Harden & motor & $1933-35$ & Panama \\
\hline Penelope & motor & $1925-35$ & Panama \\
\hline Persephone & motor & $1925-35$ & Panama \\
\hline Peter Hurll & motor & $1930-35$ & Panama \\
\hline Phoebus II & motor & $1923-35$ & Panama \\
\hline Prometheus II & motor & $1928-35$ & Panama \\
\hline R.L. Hague & motor & $1932-33$ & Italy \\
\hline Robert F. Hand & motor & 1933 & Britain \\
\hline Stansfalt & steam & $1929-30$ & France \\
\hline Svithiod (S.V. Harkness) & motor & $1929-35$ & Panama \\
\hline Thalia & motor & 1926-35 & Panama \\
\hline Urania & motor & $1926-29$ & Belgium \\
\hline Victor Ross & motor & $1933-35$ & Panama \\
\hline Vistula & motor & $1921-33$ & United States \\
\hline Zoppot (Wilhelm A. Reidemann) & motor & $1919-33$ & Germany \\
\hline
\end{tabular}

Table 1: Source: http://www.aukevisser.nl/german/; data confirmed from Lloyds Register of British and Foreign Shipping, various volumes. 


\section{A note on Bapico ship names}

At first, several of the Bapico ships were named after local geographical features in and around the Free City of Danzig. Zoppot (also spelled Sopot) was and is a small seaside beach town with a casino within the Danzig city-state boundaries; the Baltic was of course the bordering sea, while the Vistula was the river that flowed from the interior of Poland and provided Poland with the outlet to the sea that was at the core of the creation of the Free City by the League of Nations. Gedania is the Latinized form of "Danzig" or "Gdansk." Hanseat refers to the Hanseatic league, of which Danzig had been a leading member in earlier centuries.

During the period 1923-1928, Bapico chose seven names for tankers drawn from Greek mythology: Phoebus II (1923), Penelope (1925), Leda II (1925), Clio II (1926), Thalia (1926), Persephone (1928), and Prometheus (1928). The Niobe built in 1915, and from 1919 to 1927 registered in the United States, was transferred to Danzig in 1927. Several (those with the Roman numeral "II") replicated names of prior ships owned by DAPG before the Great War. Beginning in the mid 1920s, twelve ships were named after Standard Oil executives. Although available sources

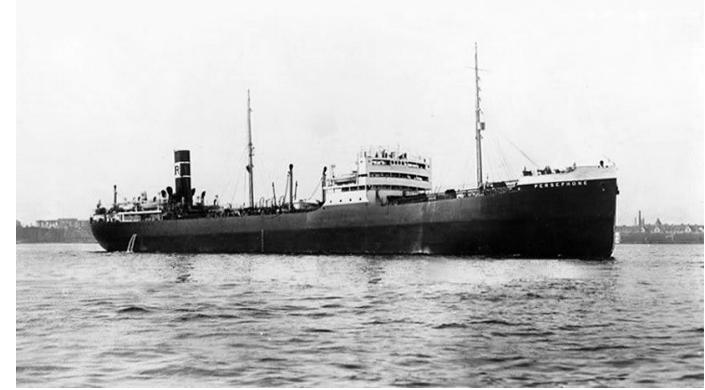

Illustration 4: Persephone. Continuing a practice from before World War One, Esso named some of its German-operated tankers registered in Danzig after Greek mythological figures.

do not show exactly why this naming procedure was adopted, it is interesting that the Standard Oil executives chosen for naming were individuals active in the international trade of Standard Oil, some of whom had special connections with the German operations of DAPG or with the Riedemann shipping firm that operated the Bapico tankers. The dominance of Esso officer names in the late 1920s is consistent with the fact that Bapico's policies were set by Esso itself. ${ }^{7}$

Auke Visser, an avid collector of data and memorabilia of Esso tankers, correctly states of the ships added in the period 1929-1933: "All were named after leading personalities of the Standard Oil and Anglo-American companies." 8 The specific individuals after whom the ships were named all had important roles in international operations of the firm. Peter Hurll and H.G. Seidel were directors of the Standard-I.G. firm that developed the synfuels process with I.G. Farben, a highly controversial move that resulted in post-World War II Congressional investigation into the relations between Farben, Standard Oil, and the Nazi regime. ${ }^{9}$ Harry G. Seidel was also the European

7 Larsen and Knowlton discuss the Bapico expansion as a feature of Esso policy, pp. 208-215.

8 Auke Visser: http://www.aukevisser.nl/uk/id545.htm This site discusses the shipbuilding tanker program of 1929-1933 in detail showing those of the Bapico-Riedemann line.

9 http://reformed-theology.org/html/books/wall_street/chapter_04.htm notes that Siedel was a

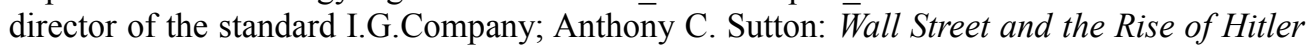


representative of Esso, and was the coordinator of marketing outside of the U.S. and Canada. ${ }^{10}$ F.H. Bedford, Jr. was also involved with the I.G. Farben firm, and supervised the sales of Esso lubricants abroad. ${ }^{11}$

J.H. Senior was head of the largest Latin American subsidiary of Esso. ${ }^{12}$ F.J. Wolfe managed the Montreal office of Imperial Oil Company, Ltd. ${ }^{13}$ George McKnight was one of the early vice presidents of Standard Oil of NJ, joining the firm in 1885 . $^{14}$ Franz Klasen was a director of DAPG. ${ }^{15}$ Robert L. Hague, a graduate of Worcester Polytechnic Institute, was Esso's general manager of the marine department. ${ }^{16}$

Josiah Macy was an historic figure, head of a firm that had been incorporated into Standard Oil in the 19th century. ${ }^{17}$ Orville Harden was a director of Standard Oil of New Jersey in the 1930s and through World War II; he died under mysterious circumstances in $1957 .^{18}$ Victor Ross had been assistant to the President of Standard Oil 1918; later president of the Imperial Oil company, successor to G. W Mayer. ${ }^{19}$

Zoppot was renamed the Wilhelm A. Riedemann. ${ }^{20}$ Wilhelm A. Riedemann had

(Cutchogue, NY: Buccaneer Books, 2004), 69. This latter source is self-published.

10 New York Times, 21 June 1981: “Gertrude S. Moffat, a Medical Student, Married to Dr. Paul E. Neumann on L.I." Seidel was a director of Standard Oil of NJ, and was killed in a Yankee Clipper crash at Lisbon in 1943. His obituary showed him as European representative of Standard Oil company, coordinator of marketing outside the U.S. and Canada.

11 Petroleum Magazine (May 1921), 69 lists F. H. Bedford, Jr., as executive of Standard Oil; F.H. Bedford Jr, shown as one of the vice presidents of Pennsylvania Lubricating Company, a subsidiary of Standard Oil: The Story of Pittsburgh, digitized e-book, n.p.; also Crime and Punishment of IG Farben, chapter 4, note 14; supervised sales of lubricants abroad, A.D. Chandler, Strategy and Structure (Cambridge: Massachusetts Institute of Technology Press, 1969), 177.

12 Senior: A.D. Chandler, Strategy and Structure, 176.

13 Wolfe: Petroleum Magazine 10 (1920), 90.

14 McKnight identified: http://archiver.rootsweb.ancestry.com/th/read/LEWIS-PhotographicNY/2010-07/1280073778 Joined Standard Oil at Pearl St. Office, Manhattan, 1885.

15 Klasen: according to http://www.wiking-schiffsmodelle.de/Projekte/Klasen small.pdf Klasen was a director of DAPG.

16 Hague: see http://www.wpi.edu/News/Journal/Spring98/mariners.html. He was an alumnus of Worcester Polytechnic Institute and general manager of the marine department. Hague's records were cited extensively by Larson and Knowlton.

17 The Wikipedia entry on Josiah W. Macy, Jr., indicates that the Macy oil company was incorporated into Standard Oil. The Macy foundation history shows that the firm was one of the first oil refineries in New York City, later incorporated into Standard Oil.

18 Harden shown as a director of Standard Oil of NJ at https://www.mtholyoke.edu/acad /intrel/Petroleum/ftc2.htm FTC hearing; also noted in Christopher Kobrack and Per H. Hansen, European Business, Dictatorship, and Political Risk, 1920-1945 (New York: Berhahn Books, 2004), p. 29, note 22 from Patent Hearings, 1942. In 1944, he was a vice president of Standard Oil of NJ, Spokane Daily Chronicle, 31 October 1944.

19 Victor Ross: "Financial News of the Oil Companies," Oil Trade Journal (Febrary 1922), 86.

20 This Esso website, http://www.crwflags.com/fotw/flags/de dapg.html, explains the history of 
established the shipping firm in 1863. The Riedemann line ships of the Bapico line all mounted a prominent " $\mathrm{R}$ " as the smokestack emblem. The timing of the adoption of Esso personnel names for Bapico ships suggests the name-change decision was made when Waried (a contraction of "W.A. Ried" emann) took over the management of Bapico.

The fact that the naming of ships at Bapico went through three distinct phases is certainly suggestive. The first batch were named after geographic features in and around the Free City of Danzig (a practice rather common among ship-owning companies actually based in Danzig); the second batch revived a pre-World War I practice at the Hamburg-based firm Waried, of naming the tankers after figures from Greek mythology. The third batch, coinciding with the shift of management to Waried directly, were named for American and international officers of Esso, ranging from historic figures to contemporary ones, all connected in one way or another to the international trade of the firm. It would seem that the first batch were intended to reflect affiliation with Danzig; the second batch made it clear that the ships were continuing the German connection, especially with several with the Roman numeral II, specifically echoing earlier names, and the third batch abandoning any pretense of Danzig or German affiliation and stressing the Esso connection. In effect, the three phases of ship-naming reflected a move from a pretense of Danzig affiliation, to an admission of German affiliation, to an outright assertion of the Esso connection. The naming practices suggest a degree of comfort with dropping any pretense of actual link to Danzig, except for the act of ship registration and flag itself. The evolution in naming away from links to Danzig, through links to the pre-war German fleet, to direct links to Esso can be seen as a growing confidence in the ability of the Danzig flag to shelter a fleet beneficially owned outside of Danzig.

\section{Danzig ships other than the Bapico Line}

In addition to the 25 Bapico ships later transferred to Panama, and seven Bapico ships transferred to other countries, other ships also registered in Danzig during the period. For the most part, they were owned and operated by local Danzig companies that operated in or from the port. Most of the companies had been established in Danzig long before World War I. The exception is the firm Artus Danziger Reederei \& HandelsAktiengessellschaft, a German firm that, like DAPG, sought refuge in Danzig to avoid confiscation and was established there in $1919 .{ }^{21}$ That line was founded by a well-known German industrialist with a reputation for sharp practices, Hugo Stinnes. It is perhaps noteworthy that all five of the ships in the German-owned Artus line were named with direct Danzig Free State references.

the W. A. Riedemann firm, which traces its history back to 1863.

21 http://www.theshipslist.com/ships/lines/stinnes.shtml; Stinnes also started a line in Hamburg at the same time, so the assertion that he feared confiscation under reparations is probably not correct. However, his choice of Danzig may have reflected concerns over the German economy and social programs. Recent research has revealed that the Stinnes line, like the Bapico line, was actually owned in Germany; as far as can be determined, all other Danzigregistered ships in the period 1920-1939 were locally-owned. Most of the biographies of Stinnes tend to be rather laudatory. 


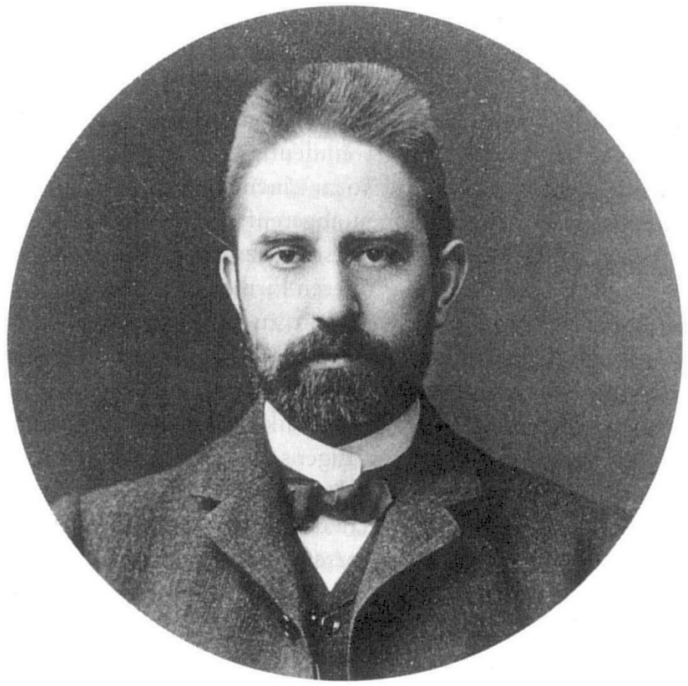

Illustration 5: Hugo Stinnes. Shown here as a young man in the 1890s, Stinnes was a wellknown German entrepreneur who developed a small fleet of ships under the Danzig flag, thereby avoiding German social legislation under the Weimar Republic.
With the exception of the five ships of the Artus line, other ships registered in Danzig during the 1920s and 1930s appeared to be owned by just a few local Danzig companies with long histories in the city. These included F.G.Reinhold (owned by Hans-Gunther Siedler) with six ships, Behnke \& Sieg with nine ships, and "Weichsel" Danzig Dampfshiffart \& Seebad with four ships. Scattered and unconfirmed records suggest at least another eight or ten ships that may have been registered in the city for various periods during the two decades, some by these companies and others by one-ship firms. Since records from the period are difficult to obtain, the list shown in Table 2 is therefore not complete. However the list represents most of the Danzig ships not owned by the Bapico line during the existence of the Free City of Danzig flag.

Table 2:

\begin{tabular}{|l|l|l|l|}
\hline Ship & Ship Type & Owner (firm owner) & Years noted in sources \\
\hline Peter Von Danzig & Passenger & F.G. Reinhold (Hans-Gunther Siedler) & 1920 s-1939 \\
\hline D. Siedler & Passenger & F.G. Reinhold (Siedler) & $1899-1933$ \\
\hline F.G.Reinhold & Cargo & F.G. Reinhold (Siedler) & $1925-1928$ \\
\hline Edith Bosselmann & Cargo & F.G. Reinhold (Siedler) & $1929-1934$ \\
\hline Marie Siedler & Cargo & F.G. Reinhold (Siedler) & $1929-1930$ \\
\hline $\begin{array}{l}\text { Oberpräsident } \\
\text { Delbruck }\end{array}$ & Cargo & F.G. Reinhold (Siedler) & $1929-1939$ \\
\hline $\begin{array}{l}\text { Weichsel (ex Queen } \\
\text { Alexandra) }\end{array}$ & Passenger & Behnke \& Sieg & $1919-1939$ \\
\hline Emily Rickert & Cargo & Behnke \& Sieg & $1891-1917$ \\
\hline Balder & Cargo & Behnke \& Sieg & $1895-1925$ \\
\hline Hansa & Cargo & Behnke \& Sieg & $1909-1925$ \\
\hline Prosper & Cargo & Behnke \& Sieg & $1904-1933$ \\
\hline Etzel & Cargo & Managed by Behnke \& Sieg & $1878-1934$ \\
\hline Mottlau & Cargo & Managed by Behnke \& Sieg & $1899-1932$ \\
\hline Echo & Cargo & Managed by Behnke \& Sieg & $1883-1932$ \\
\hline Susa (ex Echo) & Cargo & Otto Behnke (sole owner) & $1932-1935$ \\
\hline Artus & Passenger & $\begin{array}{l}\text { Artus Danziger Reederie \& Handels- } \\
\text { Aktiengesellschaft (Hugo Stinnes) }\end{array}$ & $1921-1926$ \\
\hline
\end{tabular}




\begin{tabular}{|l|l|l|l|} 
Ship & Ship Type & Owner (firm owner) & Years noted in sources \\
\hline Danzig I & Cargo & Artus (Stinnes) & 1921 \\
\hline Danzig II & Cargo & Artus (Stinnes) & $1922-1926$ \\
\hline Holm & Passenger & Artus (Stinnes) & $1921-1926$ \\
\hline Oliva & Cargo & Artus (Stinnes) & $1921-1926$ \\
\hline Lachs & Passenger & "Weichsel” Danzig Dampf.\& Seebad & c. 1925-? \\
\hline Paul Benecke & Passenger & Weichsel DD\&S & $1906-1939$ \\
\hline Richard Damme & Salvage & Weichsel DD\&S & $1928-1939$ \\
\hline Union & Tug & Weichsel DD\&S & $1931-1932$ \\
\hline Norna & n.d. & Norna Reederei & $1930-1931$ \\
\hline
\end{tabular}

Table 2: Sources for table: http://www.theshipslist.com/ships/lines/stinnes.shtml; http:// 7 seasvessels.com/?p=59210; http://oceania.pbworks.com/w/page/8465419/Klawitter; Lloyds Register of British and Foreign Shipping, Volumes 1929-1934; http://www.theshipslist .com/ships/lines/stinnes.shtml for Artus line; ship F.G.Reinhold from site: http://www .aberdeenships.com/single.asp?offset=1250\&index=100237; ship Hansa: http://www.war sailors.com/singleships/samlanes.html; http://www.plimsollshipdata.09 .

Note that Lloyds for 1931-32 indicates a total of 41 ships registered in Danzig; considering the Bapico ships and this list, that would mean that there are about another five that were registered in Danzig not identified in this research; all ships shown registered in Danzig through 1939 remained under German/Danzig registry until 1945.

Some of the passenger ships were day-excursion vessels that sailed to the nearby beach-resort Zoppot or to other local spots. As in the early years of Bapico, several of the ships were named for towns in and around Danzig, including Holm and Oliva; "Weichsel" is German for "Vistula," and "Mattlau" is a local river that flows directly into downtown Danzig. "Lachs" is "salmon" in German, the symbol of a local liqueur, containing gold flakes, Danziger Goldwasser. "Paul Benecke" was a Danzig ship captain who took the original Hanseatic ship Peter von Danzig into battle against the British in the year 1473. Richard Damme (1826-1916) was a joint founder of the "Weichsel" line. Thus, local Danzig companies, and the Artus line, like Bapico in its early years, all affirmed a Danzig connection in ship naming, through geographic, historic, or familial references. $^{22}$

\section{Bapico}

By far the largest single group or fleet of Danzig ships in the interwar period were the tankers owned by Bapico, the Baltic-American Petroleum Import Company, which was a subsidiary of the Deutsch-American Petroleum G.m.b.h. (DAPG). DAPG had been formed in 1891, with W.A. Riedemann, two other partners, and J. D. Rockefeller. By the 1930s, DAPG sold about 32 percent of the gasoline in Germany, the leader among the five largest companies. DAPG was 50 percent owned by Esso, and in 1904 moved the headquarters of the firm to Hamburg. The semi-official history of Standard Oil indicates that Bapico followed policies established by Esso in fleet

22 For Richard Damme, see: http://www.rzygacz.webd.pl/index.php?id=59,397,0,0,1,0 
expansion, choice of ship models, and transportation policies and routes, under the direction of Robert L. Hague, the head of Esso's marine department in the period. ${ }^{23}$

In 1928 and thereafter as new ships were acquired, Bapico transferred management of the fleet from Danzig to the Hamburg company Waried Tankschiff Rhederei G.m.b.H., as sole operator. Existing vessels in the Bapico fleet were transferred to management of Waried in 1928, and others acquired later, while still registered Danzig, were also managed by this Hamburg firm. The Waried company maintained its own funnel emblem and company flag, that showed a large "R," (for "Riedemann") that was on all the funnels of the Bapico ships. There were several variants of the Waried funnel emblem; photos of the Bapico ships, although in black and white, show this funnel emblem on the ships.

Circumstances suggest several reasons for the management out of the Hamburg office in 1928 :

a) The fleet's size could have made management by the Danzig office difficult;

b) Since the Bapico ships were operating for the Riedemann line (Waried) that carried oil for DAPG, it was only logical that they be operated out of Hamburg by Waried, even though registered in Danzig.

c) Danzig registry, but German operation remained convenient even after the threat of seizure of ships under reparations had receded. Waried's continued use of the Danzig registry suggests that Danzig's freedom from German social legislation, economic chaos, and labor conditions were the deciding factors.

In 1933, Hitler came into power in Germany. Also, in 1933, the Nazi party won local elections in Danzig, a month after Hitler's victory. In 1935, the whole Bapico fleet of 25 ships was transferred to Panama and was owned by a new firm, the Panama Transport Company. Whether the choice to relocate to Panama in 1935 was a business decision or a political decision, or a combination of the two, is difficult to determine from publicly available records. Larson and Knowlton attribute the decision to a mix of both factors. Citing correspondence from Standard vice-president and marine department director Hague, those authors stated:

Jersey's leaders saw in Hitler and his Nazi program a growing threat to Danzig - which could easily lose its neutral status and be taken over by Germany - and indeed a threat to the peace of Europe... In making these suggestions, Hague was in effect proposing that Jersey follow the example of several companies in their search, after World War I, for a flag that would enable ships owned in the United States to compete on equal terms with ships of other flags. ${ }^{24}$

23 Much of this story is covered in Sovereignty for Sale, 47-51; the details of the ships other than those owned by Bapico were not discussed in that treatment.

24 Larson and Knowlton, 216-217. The authors here offer the classic economic defense of flags of convenience; the assertion of contemporary concern over the Nazi regime is difficult to document, as discussed below; Larson and Knowlton may very well have made such an assertion out of hindsight and concern to clear Esso of any taint of pro-Nazi sympathy. 
The registry fee collected by Panama in June 1935 was $\$ 151,095.14$, representing less than 60 cents per Gross Registered Ton. ${ }^{25}$ The German management by Waried continued for a few years, until 1937-38, when Esso took over directly. ${ }^{26}$ The ships remained crewed by German crews until 1939, when the American-owned Panama Transport Company replaced them with Danish and American crews, repatriating the German crews to Germany, some by way of the Far East.

\section{The Danzig Registry as Flag of Convenience}

Although local ships continued to register under the Danzig flag, the Danzig registry had been a flag of convenience for the Riedemann firm over 1920-1935 and for the Stinnes-owned Artus company in the years 1921-26. The use of the Danzig ship registry as a flag of convenience was contemporary with the first uses of the Panama flag of convenience. However, Danzig registry preceded the Panamanian registry as a flag for tankers. From 1919-1935, Panama was used for an odd assortment of ships seeking foreign registry, including rum-runners, a few U.S.-owned liner ships seeking to evade Prohibition laws by serving alcohol aboard, banana transportation, and in the 1930s, for gun-running by Greeks and Basques past the neutrality (or Non-Intervention) blockade of the Spanish Civil War. ${ }^{27}$ The Norwegian entrepreneur Erling Naess transferred whaling ships to Panama beginning in 1928. Only after the Danzig fleet transferred to Panama did Panama become a flag of convenience for tankers. ${ }^{28}$

Another, and not incidental parallel between Danzig registry and Panama registry was its use for illicit purposes. In the 1930s, Sweden and Finland, which both had strict laws concerning importation of liquor, faced a problem of smuggling, or "rum-running." Danzig became a notorious departure point for the smuggler's ships. One ship, the 274 ton Willy from Danzig, was confiscated by the Lithuanians in 1936. Records indicated that at its peak in 1930, some 4 million quarts of illicit alcohol were shipped from Danzig, but that by 1934, the trade had greatly declined, due to Swedish and Finnish sea patrols. ${ }^{29}$ The U.S. Coast Guard had interdicted Panamanian-flagged rum-runners just a

25 “25 Tankers Quit Register of Danzig for Panama's," New York Times, 5 June 1935, 41.The total GRT for the 25 ships was 255,185 . If the fee was correctly reported in the New York Times, it apparently was negotiated, rather than based on a flat rate per GRT.

$26 \mathrm{http}: / /$ www.crwflags.com/fotw/flags/de dapg.html\#bapig, citing Lloyds, Waried continued to operate the fleet until 1937-38 in Panama.

27 These uses of the Panama flag are detailed in Sovereignty For Sale, 6-59. Panama was not a party to the European Non-Intervention Treaty regarding the Spanish Civil War, so its flag could legally be used to ship weapons to the Loyalist side in that war. Even so, the weapon shipments had to evade Italian patrols.

28 Erling Dekke Naess, Autobiography of a Shipping Man (Colchester, UK: Seatrade Publications, 1977); Sovereignty for Sale, 59-60.

29 "Finland Breaks up Rum-Running Group," New York Times, 19 August 1936, 9; "Control of Liquor in Sweden," New York Times, 21 August 1932, p. xx3; statistics: "Finland Ends Rum Running Off Her Coast," New York Times, 23 June 1934, 4; "The Cat and Rat Game in the Baltic," New York Times, 10 June 1932, p. SM5. The Willy was a fishing trawler, owned by F. W. Giesler, of Danzig, and registered in Panama. It was seized by the Lithuanians in April 
few years earlier during U.S. Prohibition, off the California coast. ${ }^{30}$

Well before the transfer of Esso/Bapico ships to Panama, Danzig had the classic elements of what came to be called "flags of convenience" jurisdiction after 1948: 1) it was a mini-state; 2) it needed sources of revenue; 3) the Esso fleet was not really owned by Danzig citizens, but by a German company that was a subsidiary of a U.S. company (Esso); 3) The Artus company, with Danzig registered ships, was also a German-owned firm (demonstrating that the flag was more than a one-company service to Esso); 4) the profits from the Danzig operation of Bapico were not taxed in Germany, and were plowed back into new ships, accounting for the fact that the largest Standard Oil fleet in Europe in the period 1925-1935 was the Bapico fleet; 5) operation under the flag of Danzig allowed previously German ships to avoid confiscation as part of the reparations agreement, and protected newly-built ships after 1923 from both the fluctuation of the German mark and any social legislation enacted in Germany; 6) Danzig ownership, and possibly the Danzig registry, sheltered illicit trade, as did the Panamanian flag and several later flags of convenience.

Danzig's relationship with Germany is noteworthy. Other flag of convenience states (and later second-registry states) had "special relations" with a major user of the flag. The United States had special relations with Liberia and Panama; later with Honduras, and in the 21st century, with the Marshall Islands; in later years "Second Registry" flags derived from overseas autonomous states with special relations with the metropolitan country: England and the Isle of Man; Greece and Cyprus; Netherlands and Netherlands Antilles; Spain and Canary Islands; Portugal and Madeira; and so on. ${ }^{31}$

1936 for liquor smuggling. It resisted capture with machine gun fire. The fishing boat, previously known as the Newco and the Gebrulder-Bracke, was sold after confiscation to an Estonian firm based in Tallinn, Ö/U Kalandus, and then its name was changed to Virurand. In 1939, it was again sold to a Norwegian firm and its name changed again to Röykenes. Registration records show that the boat was not using the Danzig flag as a cover for smuggling but rather the Panamanian flag. However, the fact the boat was owned in Danzig supports numerous allegations in the press that Danzig had become a center in the illicit liquor trade during the period of strict liquor control in the Baltic nations. "274 ton Danzig Steamer is Seized," New York Times, 7 April 1936; Lloyds Register of British and Foreign shipping, 1936-1939. The owner, shown in Lloyds as "F.W.Giesler," was almost certainly Friedrich Wilhelm Giesler, born 1863. See http://www.stammbaum-staeck.de/Webtrees /family.php?famid=F759\&ged=Familie\%20Staeck.ged The capture of the Willy was conducted by a smaller Lithuanian Coast Guard patrol boat, the Partazanas, under the command of Juoas Tamašauvas, armed with a 37mm gun (Miami News, 6 April 1936). Local details from local Lithuanian paper, Jura,1936, No.5, provided by Amy Jennette and Jonas Vasilevicius of the U.S. Embassy staff in Vilnius.

The following site notes that a small, 24-ton liquor smuggler's ship, the Malaya, from Danzig, was confiscated by Lithuania and turned over to the Lithuanian Sea scouts, in 1936: http://europe.seascout.org/newsletters/Euronaut/Issue_20.pdf Danzig's role in liquor smuggling may have been partly due to the extremely low price of grain alcohol in Danzig: Milwaukee Journal, 19 June 1931.

30 For Panamanian rum-runners, Sovereignty for Sale, 21-27.

31 See the treatment of Second Registries in Rodney Carlisle, "Second Registers: Maritime 
Like other flag of convenience states, Danzig was a very small national entity, with some or most of the qualities of sovereignty, which it could "market" in the same fashion that Panama and Liberia later "sold" their sovereignty. J. B. Mason, writing on the issue of Danzig's status, noted that that Danzig had exactly the kind of quasisovereignty that was so attractive in Panama, Isle of Man, Liberia, and other open registry or flag of convenience states later in the century. Mason noted that Danzig had the attributes of a state: "The independence of the Free City was restricted in several ways, but her character as a state was not thereby destroyed...We conclude, therefore, that the Free City of Danzig was a state at international law and that it was in principle vested with the sovereign rights of a state, although these had been restricted by treaty agreements in favor of Poland." 32

There was no special relation between Danzig and the U.S. but there was a special relationship between Danzig and Germany. Thus it appears that the Danzig flag, for the period 1920-1935, represented a flag of convenience for German-owned ships and showed the tax and social legislation advantages of tanker registry under a flag of convenience as a precedent for later such use in Panama in the 1930s, and Liberia in the 1950s and later. The fact that Danzig sheltered under its flag a sizeable fleet of tankers is also significant, as oil transport firms registered the vast majority of the world's tankers after the 1950s in flag of convenience states.

In the light of the later history of the Panamanian and Liberian flags of convenience, a summary of the several parallels and continuities suggests how Danzig registry fits into a pattern. Danzig, Panama, Liberia, and the Marshall Islands were all "mini-states"; they all had limited sovereignty; they all shared the same currency with the major country of ownership; three of the four (all but Panama) shared the language of the ship-owning country; they were all used for the registry of tankers.

However, it must be noted that Danzig differed in an important respect from later flag of convenience states like Panama and Liberia. Danzig had a very strong maritime tradition. It had a fairly large locally-owned and flagged merchant fleet, as shown above in Table 2. Danzig, now Gdansk, was and remains, a major ship-building city. Although Monrovia, Liberia and Colon, Panama were major ports, the maritime histories and maritime identities of those two nations did not live up to the Danzig standard.

\section{The role of Sullivan and Cromwell}

Considering the fact that Esso's attorneys were the firm of Sullivan and Cromwell, the following observation from Peter Grose, Gentleman Spy, is pertinent:

To call the Sullivan and Cromwell of the 1920s a law firm is to miss the point. The partnership of lawyers at 40 Wall Street constituted a strategic nexus of international finance, the operating core of a web of relationships that constituted power, carefully

Nations Respond to Flags of Convenience, 1984-1998," The Northern Mariner/Le marin du nord XIX, no.3 (July 2009).

32 John Brown Mason, The Danzig Dilemma: A Study of Peacemaking by Compromise (Palo Alto, CA: Stanford University Press, 1946). As discussed in chapter 14: "The Status of the Free City of Danzig under International Law,"228-248, quotation, 245. 


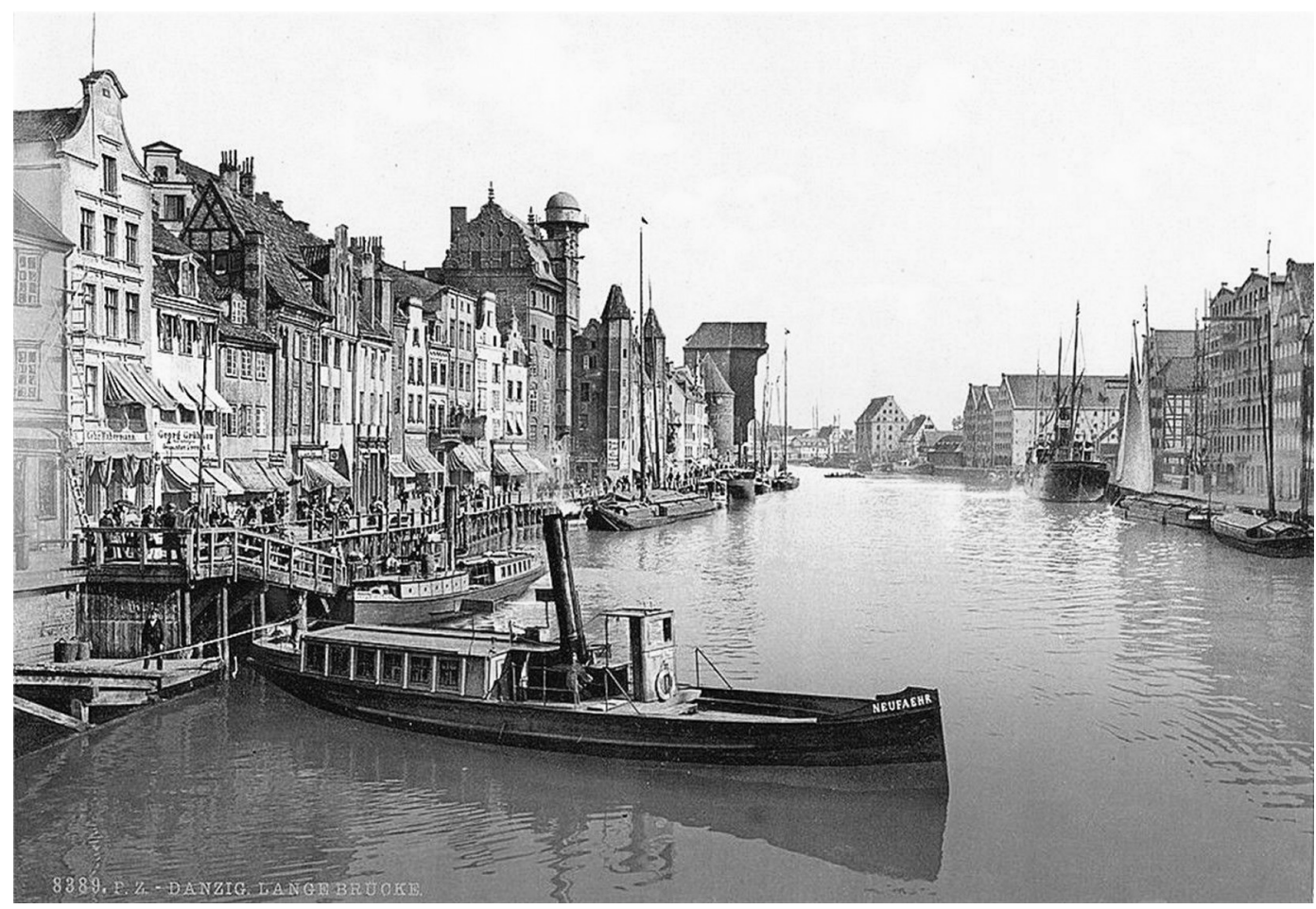

Illustration 6: Danzig. This 1920s postcard image of Danzig focused on the city's maritime heritage.

crafted to accrue and endure across sovereign borders... The firm did offer legal associates to draft contracts, preserve estates, and argue in courtrooms, but this was not the profession of law as practiced by Foster and Allen Dulles. Their Sullivan and Cromwell sought nothing less than to shape the affairs of all the world for the benefit and well-being of the select, their clients. ${ }^{33}$

Sullivan and Cromwell closed its Berlin office in 1935, at the insistence of Allen Dulles and over the objections of John Foster Dulles. The office was closed because Allen Dulles was appalled at the Nazi regime, according to several sources. This closure of the $\mathrm{S} \& \mathrm{C}$ office of the firm representing Esso in Germany may very well have been a contributing factor for the switch of 25 tankers from Bapico ownership to the Panama Transport Company of Panama and the Panamanian flag. The prior separate transfers of seven Bapico ships to Britain, Italy, Germany, the U.S. and France all appear to have been independent, business decisions. Although Esso was later accused of maintaining friendly relations with I.G. Farben and with the Nazi regime, the hasty departure of the Bapico fleet from Danzig to Panama shortly after the Nazi takeover has been used to suggest that Esso was antagonistic to the Nazi regime. ${ }^{34}$

33 Peter Grose, Gentleman Spy (New York: Houghton Mifflin, 1994), 90.

34 Since Larson and Knowlton produced a volume that, although factually accurate, also is 
Later, when Germany launched its aggressions in Europe, Grose noted, "the best that Sullivan and Cromwell could do for its European clients was to shelter their assets from war, preserving and concentrating property in neutral or otherwise secure hands. ${ }^{~} 35$ Grose pointed out that Sullivan and Cromwell and others were simply working to keep industrial assets out of Nazi hands. ${ }^{36}$ Although Germany had not launched its geographical expansion in 1935, sharp observers like Allen Dulles might very well have foreseen the disaster that would come from Nazi domination of Danzig.

There are other continuities and connections. Esso attorneys Sullivan and Cromwell had engineered the use of New Jersey incorporation in the effort to seek the most convenient jurisdiction in the United States. John Foster Dulles, with the firm, had been present at the Reparations discussions and had met with an Esso representative during those discussions. The firm had close ties with Panama (for example, they collected the

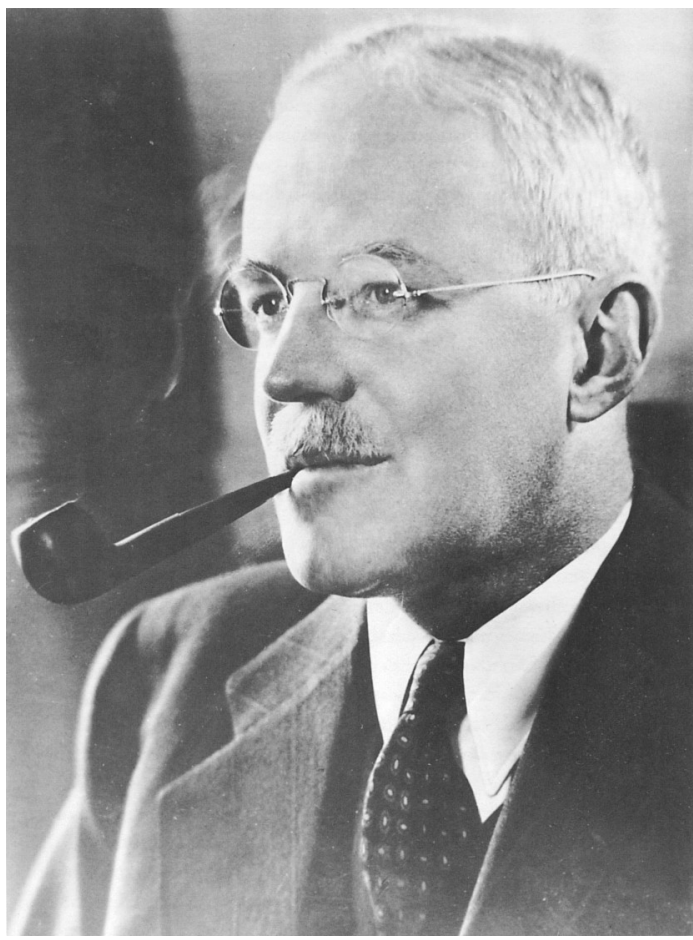

Illustration 7: Allen W. Dulles. Attorney with the law firm Sullivan and Cromwell, he advocated closing the Berlin office after the rise of Hitler. At the same time, Esso ended its registry of tankers with Danzig, moving their registry to Panama.

\section{Panama Canal Tolls), and was} instrumental in the writing of the later Liberian Code in 1948-49. ${ }^{37}$

Still another continuity is the concern over political stability, and the flight to new open registries as a consequence. In 1935, Danzig was abandoned by Esso in favor of Panama, apparently out of concern with the political instability. Esso and other companies expressed concern with the unstable regime of Panama after a period of rioting and presidential coups in 1947-49, with the emergence of a pro-fascist dictator,

quite positive in its descriptions of Esso policies, they may have had a motivation to emphasize Esso concerns with Nazi policies and possible war. Certainly in 1935, the prevailing attitude towards the Nazi regime in the United States was not one that anticipated war, so any such assertion that Esso feared for the plight of its tankers in a war with Germany appears the result of hindsight.

37 The American authorship of the Liberian Maritime Code, and the role of Esso attorneys is detailed in Sovereignty for Sale, 110-133. 
Arnulfo Arias. ${ }^{38}$ In 1949, that Panamanian instability was cited as one of the reasons for establishing Liberia as a flag of convenience. The Liberian regime, under long-time president William V. S. Tubman, appeared quite stable and American-friendly by contrast to the Arias regime in Panama. In 1992, International Registries Incorporated, the successor to Liberian Services Company, set up the Marshall Islands Registry, which attracted firms concerned with the corruption and military aggression of Liberia's government under Charles Taylor. ${ }^{39}$

The parallels and continuities with other open registry systems have gone unremarked in histories of Danzig and Germany during the inter-war years. Historical studies of the Weimar Republic have mostly concentrated on three specific issues: a) the problem of hyperinflation and its relation to the reparations issue; b) the flourishing of "modern" culture in architecture, music, the arts, and film in the period; and c) the political environment that fostered the rise of Naziism and Hitler. Treatments of maritime issues, economic and social policy, and relations with Danzig are therefore of peripheral interest to most general studies of Weimar Germany. English language historical studies of Danzig in the period have focused for the most part on relations with Poland and the efforts of the League of Nations to deal with them; and on local political issues, especially the rise of local Nazi Party. The issues of local business, shipping, maritime issues, and economic relations between Danzig and Germany are simply not discussed by most authors writing in English. Furthermore, since Danzig was totally destroyed and its German population forcibly removed at the end of World War II, there are few local records, making it difficult for researchers to work in local history. ${ }^{40}$

This close examination of the available facts regarding the Danzig registry suggests its importance. It was the first 20th century flag of convenience for tankers, setting the precedent for later such registration in Panama, Liberia, and elsewhere. The short-lived Danzig registry thus represents a "missing link" in the evolution of modern open registry and flag of convenience systems.

\footnotetext{
38 Ibid., 114.
}

39 Carlisle, "Second Registers," 335-336.

40 "The sources ordinarily used to produce local histories are largely unavailable for Danzig. The community itself was destroyed in 1945...": Herbert S. Levine, Hitler's Free City: A History of the Nazi Party in Danzig, 1925-1930 (Chicago: University of Chicago Press, 1973), 5. 